\title{
HOMO ECONOMICUS AND HOMO STRAMINEUS
}

\section{Marek Hudík}

\begin{abstract}
:
The model of Homo economicus has often been criticized as unrealistic. In particular, it has been found lacking for allegedly assuming that people are selfish, an assumption which is contradicted by both introspection and empirical evidence. The aim of this paper is to show that never in the history of the economic discipline has selfishness constituted the core of the Homo economicus model. In fact, the standard economic model of behaviour which has been used by economists for more than a hundred years is reticent about the motives of behaviour. Critics thus do not criticize Homo economicus but a straw man - Homo stramineus. Three possible reasons for confusing Homo economicus with Homo stramineus are identified: malicious intent, ignorance and an attempt to avoid the tautological model of behaviour.
\end{abstract}

Keywords: Homo economicus, self-interest, desire of wealth, utility, rationality.

JEL Classification: B12, B13, B21, B41, D01

\section{Introduction}

Critics of the standard behavioural assumptions of economics have been heaping arguments and empirical evidence in support of the claim that people are not selfish in the narrow sense of maximizing personal material gain. For instance, Bowles and Gintis (2000) criticize the concept of Homo economicus for purported neglect of non-selfish motives, Fehr et al. (2002) challenge (the narrowly conceived) 'self-interest assumption' which, according to them, dominates the behavioural sciences, and Henrich et al. (2005) attempt to refute what they call the 'selfishness axiom', i.e. "the assumption that individuals seek to maximize their own material gains [...] and expect others to do the same" (Henrich et al. 2005:797). These works just echo a mass of much older literature (e.g. Barton 1830; Hildebrand 1848; Ruskin 1862[1860]; Carey 1865; Thompson 1875; A. K. Sen 1977; Caporael et al. 1989; Elster 1989; Etzioni 1990) which, in one form or another, criticized the assumption of selfish behaviour as the basis of economics.

The aim of this paper is to present the evolution of Homo economicus in order to demonstrate that selfishness in the history of the economic discipline never constituted the core of the Homo economicus model. In fact, it was only in the period of classical political economy that Homo economicus was assigned certain motives; and even then the assumed motives were not necessarily selfish. Later descriptions of this life form mentioned no particular motives whatsoever. It thus appears that critics have actually been attacking a different species to Homo economicus, namely, Homo stramineus - straw man.

* Marek Hudík, Center for Theoretical Study, Charles University, Prague, Czech Republic (hudik@cts.cuni.cz). Author would like to thank Petr Houdek, David Lipka, Pavel Pelikán, Dan Štastný and an anonymous PEP referee for helpful comments. The usual caveat applies. 
This paper is complementary to earlier historical accounts of Homo economicus, such as Viner (1925a, 1925b), Stigler (1950a, 1950b), Houthakker (1961), Kauder (1965), Machlup (1972), and Kirzner (1976). None of these works, however, reflect the recent evolution of economic man, nor do they - with the notable exceptions of Machlup (1972) and Kirzner (1976) - focus on the alleged selfishness of this creature.

This paper is organized as follows: Section 2 presents the views of classical economists who thought of Homo economicus as a wealth-seeking animal. Later, in the period which coincides with the marginalist revolution, economists characterized this species first, through an economizing procedure and then through the ability to make choices; this development is the subject of Section 3. In Section 4, the standard version of Homo economicus, defined through the consistency of choice, is presented. Some refinements to the standard model of economic behaviour are discussed in Section 5. Section 6 attempts to explain why the two species - Homo economicus and Homo stramineus - have often been so confused. Section 6 provides a conclusion to the paper.

\section{The Economic Motive}

The roots of the Homo economicus concept must be sought in the works of the classics. ${ }^{1}$ Nonetheless, we must bear in mind that classical political economy was not understood as the Robbinsonian 'science of behaviour' but rather as the 'science of wealth', or more precisely, of the production and distribution of wealth (e.g. Senior, 1831[1827], 1854[1850]; Say, 1836 [1803]; Mill, 1844, 1909; Cairnes, 1875 [1857]). Consequently, behavioural assumptions of classical political economy were largely implicit and if discussed explicitly, it was done so in the context of what could be called the methodology or philosophy of economics rather than within the science itself. Political economy as such was satisfied with merely postulating the common-sense assumptions such as that which people choose to buy cheaply and sell dearly, without having elaborated a theory of choice; in fact, some economists (e.g. Mill, 1844) excluded consumer choice from the realm of political economy altogether since the 'destruction' of wealth (of which consumption, according to them, essentially consisted), unlike its creation and distribution, seemed to be of no particular interest. Yet classical economists did believe that the laws of political economy have their roots in 'human nature'2 and the philosophically-minded explored these roots. To give an account of the classical economic man, we must therefore turn to these authors.

The classics interpreted behaviour of people that populated their theories as driven by a 'wealth motive'. More specifically, they adopted the view that each individual "desires to obtain additional wealth with as little sacrifice as possible." ${ }^{3}$ Note that this proposition

1 Of course, classical economists built on already existing ideas (see e.g. Force, 2003) for the discussion of the pre-classical idea of self-interest). Nevertheless, to adopt Smith's Wealth of the Nations as the starting point of the analysis is not based primarily on Smith's originality (which is notoriously questionable) but on the fact that Smith started a tradition of criticism and gradual improvement of his work. Without much exaggeration we may paraphrase Whitehead (1979[1929]:39) in saying that all economics consists of footnotes to Smith. Compare also Stigler (1976).

2 According to Hudík (2011), this idea also remains implicit in modern economics and is criticized by him as a form of 'psychologism'.

3 This particular formulation is Senior's (1854:26); however, we can find similar statements with minor variations in the works of other economists. Compare Schumpeter's (1994[1954]:549) 
involves an assumption not only about a particular motive (wealth) but also about the procedure of economizing ("as little sacrifice as possible"). However, it was above all the former that was considered as the crucial assumption and which also came under fire by the critics of the then-young discipline. Let us now have a closer look at what was meant by the 'wealth motive' and how it fits within the classical view of human nature.

First of all, we must specify what, according to the classics, constituted 'wealth'. Although there were some disagreements about the definition, the classics arrived at something very close to what Menger (1950) later called 'economic goods': more specifically, wealth, consisted of things that are (i) capable of producing pleasure or preventing pain (i.e. which are useful), (ii) limited in supply and (iii) transferable (Senior, 1854[1850]:6). ${ }^{4}$ Now since items of wealth are transferable, they have a market price and can thus be obtained for money. Therefore, the 'desire for wealth' can be considered identical with the 'love of money', as money is a means to obtain goods - and indeed, it seems that the classics used the terms 'wealth' and 'money' interchangeably in this context (but not on a macro level), thinking of money as 'abstract wealth'. ${ }^{5}$

It must be emphasized that the classics did not say that men desire only wealth or that they desire any form of wealth. They were perfectly aware that there were wants which can be satisfied by means other than economic goods. This recognition precluded the naïve interpretation of the classical economic man, according to which there was a self-contained wealth motive embedded in human nature; it was realized that this wealth motive, in fact, involved a great variety of motives of different natures. ${ }^{6}$ Hence, a more appropriate characteristics, of the 'wealth motive' is that "every person has some unsatisfied desires which he believes that additional wealth would gratify" (Senior, 1854[1850]:27).

The realization of the fact that wealth is thus just a means of attaining many (but not all) heterogeneous ends opened the door to shifting the emphasis away from the motives of behaviour towards the process of economizing as the main characteristics of economic man (Kirzner, 1976:61). Such a shift came only with the marginalist revolution and is discussed in more detail in the next section. For the purpose of this paper the most important

statement that Senior's proposition would "fit into Ricardo's or Malthus' texts" and that "Adam Smith and J.S. Mill took it for granted." I continue to base the characterization of economic man in this section mainly on Senior's (1854) lucid exposition.

4 The classics differed in opinions on several points; firstly, there was no consensus whether only material things should be included (as argued by e.g. Malthus (1836[1820], 1827)) or also immaterial (as argued by e.g. Senior (1854) and Say (1840[1828-1830]). Secondly, the condition (ii) was introduced to exclude what has later been called 'free goods'; some authors achieved nearly the same result by requiring instead of (ii) that the articles of wealth must be products of human labour. The latter assumption was obviously less general but, on the other hand, had the advantage of being in line with the classical labour theory of value. With the demise of the labour theory this alternative was abandoned. For the discussion see also Menger (1950:288ff).

5 Identifying wealth with money is a bit problematic because it can be done only on an individual level and not on an aggregate ('national') level (and it will be remembered that classics were concerned especially with the wealth of nations and not individuals) which implies some differences between 'personal wealth' and 'national wealth'. This complication seems to have made J. S. Mill not deal with the definition too much and he thought that "every one has a notion, sufficiently correct for common purposes, of what is meant by wealth" (J. S. Mill 1909[1848]:1).

6 This, to the present reader, quite obvious idea seems to have been overlooked by Bentham (1817) and Mill (1844). It was especially emphasized by Leslie (1997[1862]) in his well-known article The Love of Money, who believed that by pointing it out he was refuting the concept of economic man. 
consequence of this insight was that the 'desire of wealth' cannot be identified with egoism, or indeed, any particular trait of human nature. ${ }^{7}$ As wealth can serve as a means to satisfy any ends, including altruistic, it is mistaken to assume that economics presupposes 'selfishness', 'self-interest' (narrowly understood), 'avarice', 'lower elements of human nature' or the like. This was pointed out more or less explicitly by a crowd of classical economists, such as Smith $(2008[1776])^{8}$, Whately $(1847[1832])$ or Senior $(1854[1850])$, it was repeated again by some of the early marginalists, e.g. Newcomb (1966[1885]), Böhm-Bawerk (1959[1889]), Marshall (1982[1890]), and Wicksteed (1957[1910]) and it has been occasionally remained until today (see e.g. Ostrom, 1998 and Smith, 2007).

Thus, for instance, Whately (1847[1832]:26) assures his readers that "wealth has no more necessary connexion with the vice of covetousness, than with the virtue of charity; since it merely forms the subject-matter about which the one as well as the other of these is concerned"; on a similar note, Whately's student Nassau Senior writes:

Some may wish for power, others for distinction, and others for leisure; some require bodily, and others mental amusement; some are anxious to produce important advantage to the public; and there are few, perhaps there are none, who, if it could be done by a wish, would not benefit their acquaintances and friends. Money seems to be the only object for which the desire is universal; and it is so, because money is abstract wealth. Its possessor may satisfy at will his ambition, or vanity, or indolence, his public spirit or his private benevolence; may multiply the means of obtaining bodily pleasure, or of avoiding bodily evil, or the still more expensive amusements of the mind (Senior, 1854[1850]:27).

We are now able to provide a relatively complete picture of the classical view of 'human nature'. First it was assumed (especially under the influence of $18^{\text {th }}$ century neo-Epicureanism and $19^{\text {th }}$ century utilitarianism) that ultimately there is one sole end - human 'happiness', or, equivalently, 'utility', 'pleasure', or (broadly defined) 'self-interest' (Smith, 2007[1759] and Whately, 1847[1832]) are examples of authors who make this commonly shared assumption explicit. These terms must not be understood in a hedonistic (psychological) sense but rather in a formal (non-psychological) one as being capable of including any possible human desire. ${ }^{9}$ Happiness encompasses various kinds

$7 \quad$ Hence also not with prudence as suggested by McCloskey (2011). Such identification holds even less for 'Samuelsonian economics' (see Section 4). For a criticism of McCloskey's view see Lipka (2012).

8 The so called 'Adam Smith problem', according to which the father of Political Economy in his Wealth of Nations assumed that people are selfish while at the same time assuming their benevolence in his Theory of Moral Sentiments, has now been recognized for a long time as a pseudo-problem. See e.g. Griswold (1999) or Pavlík (2004).

9 This also turns out to be Marshall's (1982[1890]:14) and Mises's (2003:160) interpretation of the classical view of happiness. It seems that even Bentham used the term in the formal sense. It is true that he thought of pain and pleasure as "homogenous real entities" (Bentham 1907[1823]:22n), in principle capable of measurement, which suggests a hedonistic rather than formal interpretation; on the other hand, he often uses the term in a circular sense as in his defence of the 'principle of utility' (Bentham 1907[1823]:1, 11-12), pointing out that the principle of utility cannot be criticized without a reference to it (an argument principally the same as the one used by Hoppe (1995:22), according to which the statement that "humans act" cannot be "undone"). Elsewhere, he also writes: "Constantly actual end of action on the part of every individual at the moment of action, his greatest happiness, according to his view of it at that moment" (Bentham 1843:560). His point appears to be that there cannot be an unmotivated action (no matter what the motive is) (Bentham 1817:15). The same 
of motives or interests, $M_{1}, \ldots, M_{n},{ }^{10}$ some of which, say, $M_{1}, \ldots, M_{m}$, can be gratified with items of wealth, i.e. economic goods, while these goods can be purchased for money (see Figure 1).

Figure 1 | Classics' View of Human Nature

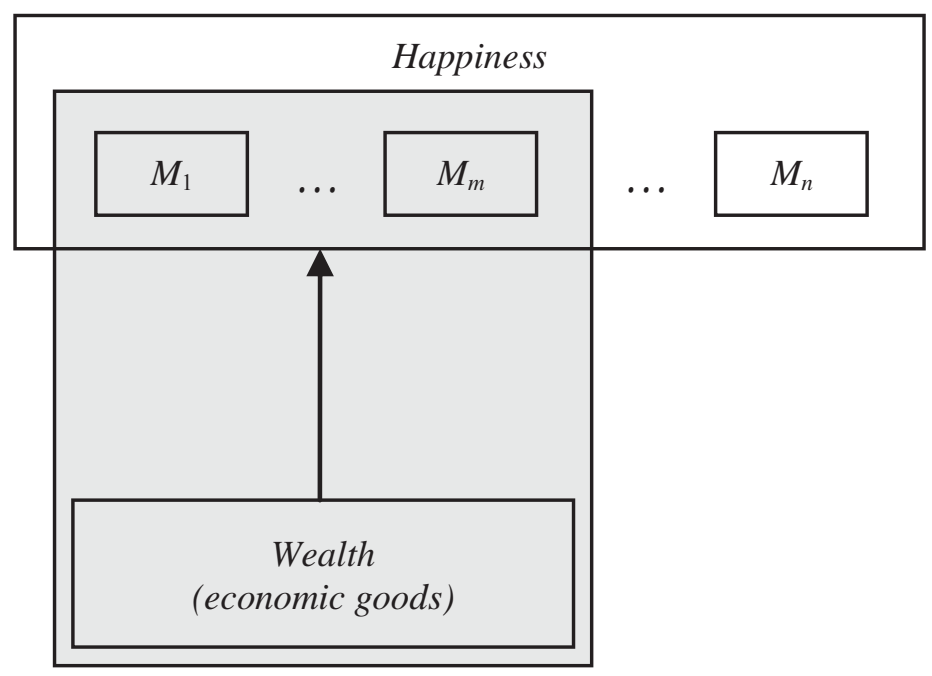

Note that the classical view of 'human nature' was by no means narrow; even though classical economists professed to studying phenomena that arose solely from the pursuit of the 'desire of wealth', they were aware that when they wanted to apply the model to reality they had to take into account the motives they previously abstained from. They were also aware that "with respect to those parts of human conduct of which wealth is not even the principal object, to these Political Economy does not pretend that its conclusions are applicable" (J. S. Mill, 1844:139). Unfortunately, classical economists were not able to explain, why certain desires prevail in certain situations and other desires in other situations (Kirzner, 1976:29). For them, this was rather a problem of application of the theory not of the theory itself.

We shall see that further elaborations of Homo economicus were nothing but refinements of this classical model. In the next Section I will show that these refinements consisted firstly, in the shift of the focus away from motives towards the mental processes (economization) and secondly, in the formalization of the theory which made it easier to expose its implicit assumptions to the light. Both these tendencies had the effect that economists become less and less interested in the problems of 'human nature'.

seems to hold about the neo-Epicureans; for instance, d'Holbach, writes: "no man can be called disinterested. We call a man disinterested only when we do not know his motives, or when we approve of them." (cit. in Force 2003:12).

10 Bentham (1817) recognized fourteen of them. 


\section{Economic Process of Thought}

The so-called marginalist revolution elevated economic man from the philosophy of economics to the very subject matter of this science. And - as far as the concept of economic behaviour is concerned - it was hardly a revolution. The ideas of the previous period were by no means negated; they were simply made more precise with the help of marginal analysis. That is to say, the classics did not have a different model of behaviour; they only had an underdeveloped one because, as already mentioned, they were not particularly interested in behaviour as such. For example, where Mill writes that the motive of wealth is "checked by the two perpetual counter-motives [aversion to labour and desire of the present enjoyment of costly indulgences]" (J. S. Mill, 1844: 138), Jevons (1965[1971]: 174-177) supplies a mathematical formula for equalizing marginal disutility of labour and marginal benefit from labour induced by an increase of wealth. ${ }^{11}$ The classics would also not object to the law of diminishing marginal utility (in fact, it is commonplace that this law was known and accepted by some of them); they just did not make it the basis of their theory. ${ }^{12}$ They focused on the problems of production and distribution and not on the theory of consumption and exchange. In effect, their theory was too coarse to explain the behaviour of the consumer: once the consumer earned his income, he was able to purchase any economic goods he pleased and the analysis was not concerned with how he divided his income among various goods. ${ }^{13}$ Marginalists, on the other hand, realized that the problems of consumption and exchange cannot be neglected when the classical problems of production and distribution are discussed (cf. Marshall 1982[1890]:70-71). In the words of Jevons (1965[1871]: 40), "the theory of Economics must begin with a correct theory of consumption."14

As the problem of the allocation of goods to various uses became central, the concept of economic man needed to be refined. As mentioned earlier, this refinement consisted in particular in the shift away from the motives of behaviour (since it was accepted that 'economic man' is allowed to have any - or almost any - motives) towards the choice procedure. Admittedly, many marginalists did partly discuss motives, desires and wants and 'human nature' in general (Menger, 1950; Marshall, 1982 [1890]; Böhm-Bawerk 1959[1889]). However, they usually followed Jevons' advice to transfer the "attention as soon as possible to the physical objects or actions which are the source to us of

11 The process of translation of Homo economicus into mathematical language is not discussed here. Any interested reader may consult Stigler's (1950a, 1950b) brilliant account.

12 See e.g. Stigler (1950a), Kauder (1965) and Hayek (1991). The last mentioned points out that "every single one of their [Menger's, Jevons' and Walras'] basic ideas had repeatedly and clearly been set forth in earlier works" but it was only these 'revolutionaries', who "made the insight into the nature of economic values [...] the point of departure for self-contained systems of theoretical economics" Hayek (1991:365). Since marginalism was not the crucial innovation of the marginalists, Hicks (1983:9-10) even rejects the term 'marginalist revolution' as inappropriate.

13 Hence Mises's (1996:63) claim that the classics could only explain the behaviour of businessmen.

14 Admittedly, some marginalists accepted Mill's argument that the act of consumption is not an economic problem. Thus Wieser (2003:43), writes that "consumption as such, the satisfaction of needs as such, is not an economic act at all." 
pleasures and pains" (Jevons, 1965[1871]:37). ${ }^{15}$ And as the mathematization of the theory proceeded, the discussions of motives became less frequent. ${ }^{16}$

If the marginalist version of Homo economicus is to be characterized by one principle only, it is the principle of allocation of scarce means in order to maximize his utility. It was precisely this focus on the process of economizing that gave the impression to both, practitioners of science and commentators (such as Veblen, 1898), that Homo economicus must be 'rational' in the commonsense meaning of the term, i.e. that he adjusts means to given ends by using his reason. Indeed, economists of the period pointed out that they dealt with the rational side of human nature and abstained from traditional, emotional or reflexive behaviour. ${ }^{17}$ Thus for instance Wieser $(2003: 43)$ labels the theory of consumer behaviour as 'economic management' and Wicksteed (1957[1910]:76) speaks of the 'art of successful administration'. Although the economizing procedure could also be applied in non-market decisions, economists for the moment stick to the notion (attributed to Pigou and also entertained by Marshall) that economics deals with the area of human welfare which can be "measured by the yard stick of money" (Kirzner, 1976:95-96). Figure 2 illustrates the updated version of Homo economicus.

\section{Figure 2 | Marginalist Homo Economicus |}

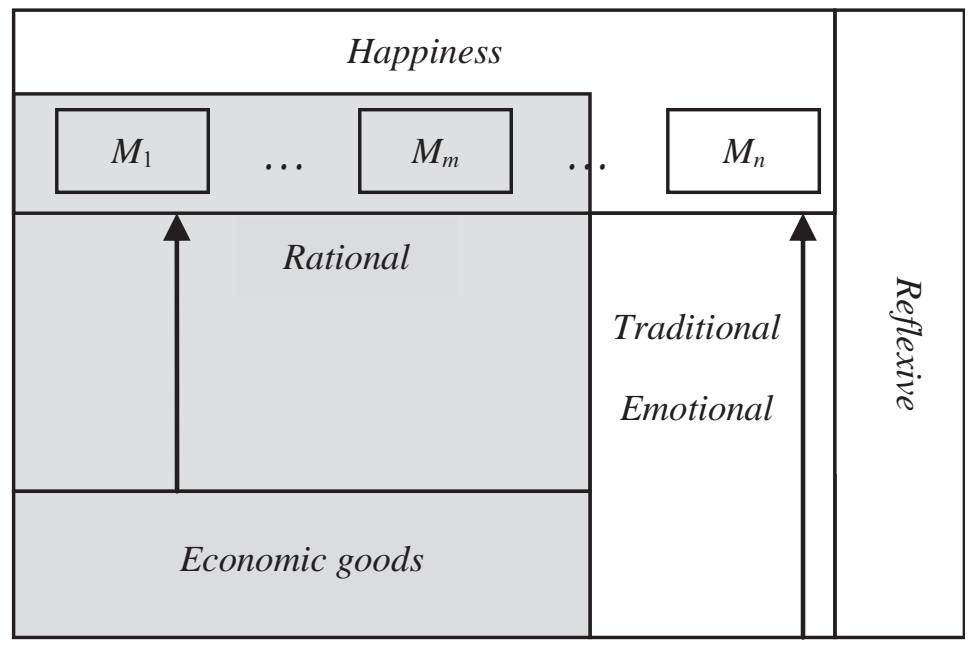

15 See also Pareto (1971), whose views in this respect has been recently criticized (Bruni and Sugden 2007). Slutsky (1998) had practical reasons for eliminating the questions concerning 'human nature': according to him, these questions are subject to as yet unresolved controversies of which economic inquiry is largely independent.

16 One of the exceptions was the now almost forgotten economist František Čuhel, who wrote a detailed monograph on the theory of needs. For a summary of Čuhel's contribution see Hudík (2007).

17 See Weber (1978[1922]). There were some terminological differences among authors: they would talk about 'deliberateness' (Marshall, 1982[1890]), 'purposefulness' (Engliš, 1992; Mises, 1996) or economizing (Menger, 1950). According to Jevons (1965[1871]), utility maximization holds for a "perfectly wise being". 
Critics of this version of economic man were quick to point out that human behaviour is very often not deliberate (not even in the markets) and is subject to custom and tradition (Hadley, 1894; Tugwell, 1922; Mitchell, 1910b, 1910a; Downey, 1910). A reply to this objection was that habits themselves are subject to choice (Marshall, 1982 [1890]; Wicksteed, 1957[1910], 1970[1888]; Davenport, 1968[1914]). As put by Wicksteed (1957[1910]:121), "the ideally wise man will not only think wisely, but will know how much to think and when not to think at all." 18 In fact, it was realized that it does not really matter whether any reasoning really precedes an action or not: as far as an individual can change his mind and do something else, then the economic model applies. Thus the traditional, rational and emotional types of behaviour have been pooled together and the dividing line only remained between intentional and reflexive behaviour, over which a person does not have control, or, in other words, between action and reaction (Mises, 1996[1949]). To use terms introduced by Simon (1986), economics moved from 'procedural rationality' towards 'substantial rationality'. ${ }^{19}$ This broad concept of economic behaviour opened the door for the application of the economic model to any behaviour which could be moulded to the means-ends structure (Robbins, 1945[1932]); nevertheless, this extension of the model materialized only much later in the works of Becker (1976, 1998[1996]).

Encompassing traditional and emotional behaviour into the model of economic man would, however, not persuade the critics: they would argue that traditional and emotional behaviour very often does not produce 'happiness'; therefore, such a solution was inadequate. It was then necessary to show that when economists talk about 'happiness' or 'utility' they do not have in mind any psychological magnitude but rather 'significance' or 'importance' of a thing for the individual. And economists were eager to do so, at least on a rhetorical level: in order to avoid confusion they suggested various terms to substitute for the misleading terms 'happiness' and 'utility'. These were: 'desirability' (Fisher, 2007[1892]; Gide, 1933[1883]), 'desiredness' (Wicksteed, 1970[1888]; Pigou, 2006[1920]; Davenport, 1902), 'ophelimity' (Pareto, 1971) or 'wantability' (Fisher, 1918). None of these terms took root and economists remained faithful to 'utility'.

On a more fundamental level, it was proved that for the purposes of economic theory one can get along with the ordinal concept of utility: Hicks and Allen (1934a, 1934b) and Hicks (1946[1939], 1986[1956]), building on the earlier contributions of Fisher (2007[1892]), Pareto (1971) and Slutsky (1998[1915]), demonstrated that it is enough if an individual is able to rank the alternatives according to the importance to him. In fact, the economic theory could be built without any reference to 'utility' whatsoever. And if economists have occasionally been speaking of 'utility', it must neither be understood as a motive of behaviour, nor is it appropriate to associate it with particular motives; it

18 Marginalists were probably not aware of the infinite regress involved in this kind of reasoning: if decision costs are greater than zero then the 'wise man' must determine how much to 'think' about the decision problem $D$, then how much to think about the problem 'how much to thing about $D$ ' and so on. This problem continues to be emphasized by choice theorists who believe that rationality in economics involves employment of reason. See e.g. Conlisk (1996).

19 To use the term 'rationality' to describe the notion behind 'substantial rationality' is not very fortunate since it mistakenly suggests the use of reason in decision-making and tends to give birth to another type of straw man, which, due to limited space, cannot be discussed in detail within this paper. 
is a mathematical construct representing individuals' preferences whose existence is not assumed in reality. ${ }^{20}$

Figure 3 illustrates the new version of Homo economicus, which, unlike the earlier versions, works with ends and means in the abstract. For the ends one can substitute desires, motives or wants and for the means the economic goods; alternatively, economic goods can be substituted for the ends and money for the means. Note that while the earlier version of economic man still excluded certain motives from the realm of economics (those were typically ethical motives ${ }^{21}$ ), this version sees no technical difference between any possible kinds of ends (Mises, 1996[1949]).

\section{Figure 3 | Marginalist Homo Economicus II}

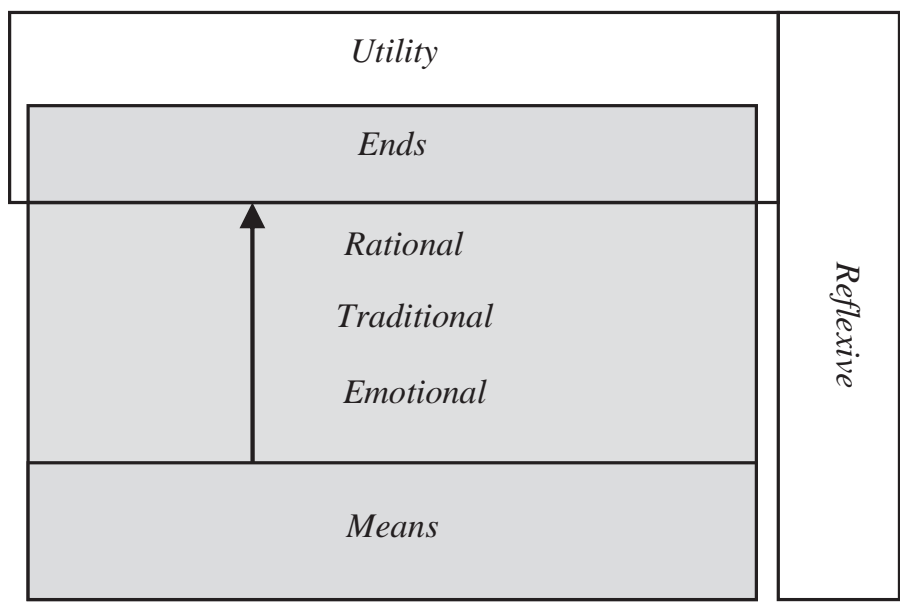

\section{Economic Pattern of Choice}

There was one more important change taking place in the period between marginalist revolution and World War II: economists were able to precisely formulate the purpose of the Homo economicus model. While the classics were looking for the foundations of the whole of economic theory in 'human nature' without specifying what exactly should be included in the whole of economic theory, marginalists set themselves a much more specific task: to derive the downward-slopping demand curve with minimum assumptions (Viner, 1925a; Houthakker, 1961; Samuelson, 1974[1947]; Syll, 1993). The effect of this research programme was that economists lost interest in 'human nature': no specific assumptions about 'human nature' were needed to obtain facts of the demand theory.

20 Binmore (2009:19) calls the confusion of the formal notion of utility with pleasure 'causal utility fallacy'. J. S. Mill's note in his father's book Analysis of the Phenomena of Human Mind is relevant in this context: "The tendency has always been strong to believe that whatever received a name must be an entity or thing, having an independent existence of its own; and if no real entity answering to the name could be found, men did not for that reason suppose that none existed, but imagined that it was something peculiarly abstruse and mysterious, too high to be an object of sense" (J. Mill, 1869:5n).

21 See Weber (1978[1922]) who distinguishes between instrumentally rational (zweckrational) and value-rational (wertrational) action. 
Economists stopped asking why a certain alternative was chosen; they were satisfied with the fact that it was chosen. While the classical and early marginalist model could be considered an explanatory model of behaviour (behaviour being explained by motives), the new model was purely descriptive (Rosenberg, 1992; Binmore, 2009). This new version of Homo economicus can be represented as in Figure 4: preferences represented by a utility function are defined in the means (e.g. economic goods), while nothing is said about ends. A choice procedure is also not explicitly specified.

\section{Figure 4 | Neoclassical Homo Economicus}

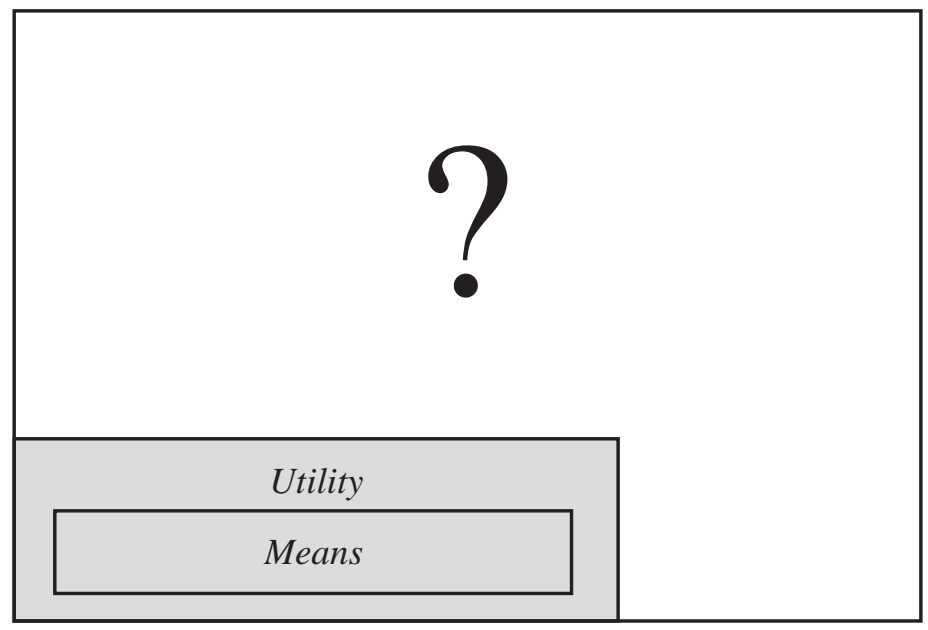

This 'minimalistic' concept of Homo economicus stemmed from yet another tendency: economists realized that more complex models of behaviour were not operational because they required information on the side of an economist about people's desires and thought processes. But economists found themselves largely ignorant about what was going on in people's heads. This led to the situation that some economists even became uncomfortable with the model depicted in Figure 4 since it involved an unobservable concept of preference or (ordinal) utility. The problem was taken up by Samuelson (1938, 1974[1947]) who was able to define Homo economicus in terms of observable choice behaviour: it was now required that individuals' choices satisfied the following property: if an alternative is chosen and is available, then when is chosen must no longer be feasible. If an individual's choices are consistent in this sense then he behaves as if he was maximizing something even though we do not know what it might be or whether he was maximizing at all. ${ }^{22}$ This is Samuelson's famous revealed preference theory which eventually fulfilled Viner's prophetic words: "The time seems to be approaching when there will be a utility economics which carefully avoids employing the term which originally gave it its name!" (Viner, 1925b:641).

22 For precise formulation and proofs see e.g. Mas-Colell et al. (1995). An account of the revealed preference theory after Samuelson is provided by Varian (2006). Rubinstein (1998) gives examples of several non-maximizing choice procedures which give rise to consistent behaviour. 
While the revealed preference theory or, alternatively, the preference- or utility-based approaches depicted in Figure 4 remain the standard models of economic behaviour, in the next section I shall demonstrate that according to some economists the reduction of Homo economicus went too far and that it seems necessary to take agents' motives into account.

\section{Getting Motives Back into the Picture}

After Homo economicus reached maturity with ordinalism and revealed preference theory he was able to produce offspring who coexist with him in the economic habitat. In this section I give two examples of authors who - guided by their dissatisfaction with the 'minimalistic' version of economic man - the father - helped to give life to some of his children. These authors are Amartya Sen and Gary Becker. I discuss their contributions in turn.

According to the revealed preference theory, the Homo economicus model fails, if we observe that $x$ is chosen from the set $\{x, y\}$, while $y$ is chosen from the set $\{x, y, z\}$, Consider now the following two examples:

Example 1 (Luce and Raïfa, 1989[1957]): A customer chooses salmon from a menu in a restaurant consisting of $\{$ salmon, steak\} and steak from a menu $\{$ salmon, steak, frog $\operatorname{legs}\}$.

Example 2 (Sen, 1993): A decision maker accepts an invitation for tea at a distant acquaintance's home; he rejects the invitation if he is offered the possibility of also having some cocaine.

The two examples seemingly represent a violation of the consistency assumption; yet, they can be interpreted in a way that they are in line with the Homo economicus model. It can be the case that $y$ in set $\{x, y\}$ is not the same as $y$ in set $\{x, y, z\}$ : in the restaurant example the presence of frog legs on the menu may signal the high quality of the chef and so the steak on the second menu is of high quality, while the quality of the steak on the first menu is uncertain. Likewise, the possibility to snort cocaine in the second example provides additional information about the character of the tea party, so the invitation with the possibility of having cocaine and the invitation without this possibility are not quite the same.

According to Sen (1993), examples such as those two above prove that when examining consistency, something external to choice behaviour (such as objectives, values or norms) is always needed. An implicit response to Sen's insight includes models by Bernheim and Rangel (2007), Salant and Rubinstein (2008) and Rubinstein and Salant (2012), who extend the standard model of choice by explicitly incorporating framing into it.

Turning now to Becker, his dissatisfaction with the standard model of Homo economicus was of a different sort to Sen's. He observed that the standard model assumes preferences defined only on one set of means, i.e. economic goods, while ignoring another set of means employed by individuals to achieve their goals, namely various uses of time. In order to incorporate this insight in the model, he uses an analogy with firm behaviour by assuming that individuals choose technologies to 'produce' their goals. Becker calls these goals 'commodities' and includes among them health, prestige, sensual pleasure, social standing, etc. His model is schematically depicted in Figure 5. 
Figure 5 | Becker's Homo Economicus

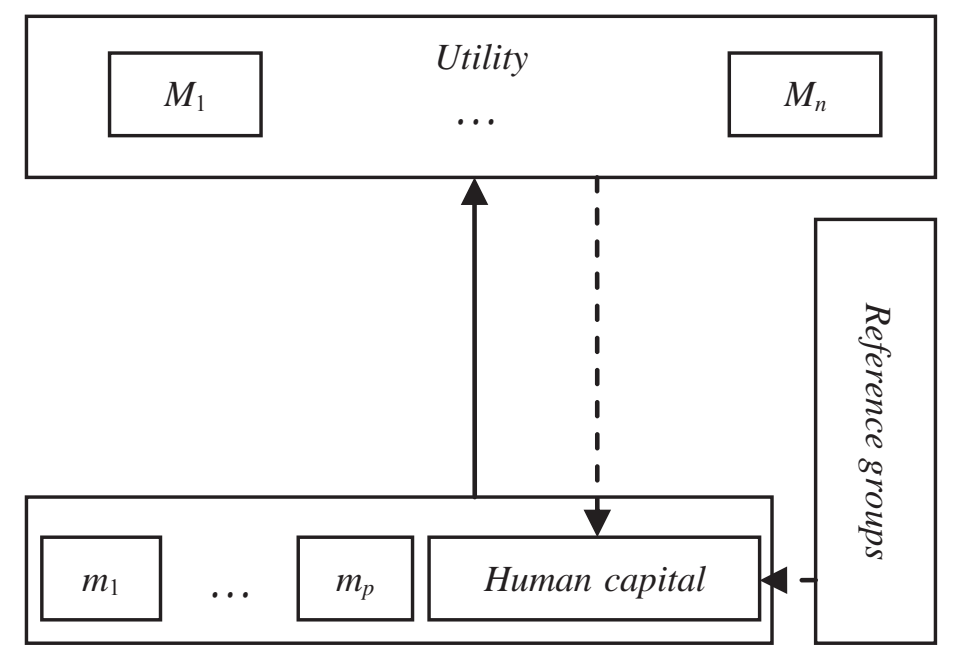

If we compare Becker's model with the classical view of 'human nature' (Figure 1), it can be concluded that no substantial change in those almost two hundred years has occurred. ${ }^{23}$ Slight differences are the following: first, unlike the classics, Becker does not restrict economics to a particular group of motives - any behaviour can be subject to economic analysis (Becker, 1976:14); second, Becker introduces the concept of human capital which can account for the individual's past experience (personal capital) and the influence of reference groups (social capital). The idea that past behaviour and peer pressure influences choices is uncontroversial and there is probably no economist in history that would reject it; yet, Becker is the first economist who was able to formalize it and incorporate it into the model.

For the purpose of our paper it is important to emphasize that neither Sen nor Becker suggested that economists should consider only one particular motive, such as selfishness or narrowly defined self-interest. Homo economicus, unlike Homo stramineus, is capable of embracing any motive of behaviour, no matter how outlandish. In fact, our brief historical excursion warrants the conclusion that never in history did the concept of Homo economicus involve the idea of selfish behaviour. The standard $20^{\text {th }}$ and $21^{\text {st }}$ century model of economic behaviour does not refer to any motive whatsoever.

23 Becker (1998[1996]:164) is aware of the similarity of his model with the classical one since he explicitly quotes Bentham. See also Force (2003:95) who points out similarity between Bentham and Becker and Cowen (1989) who relates Becker's views to Menger's. 


\section{Causes of Misunderstanding}

Having demonstrated that Homo economicus significantly differs from Homo stramineus, the question now arises as to why the two have so often been confused.

One explanation was suggested by Mises (2003[1933]:160) who, with reference to the early doctrines of Epicureanism and utilitarianism, claimed that the ideas were "deliberately misrepresented, caricatured, derided, and ridiculed" (Mises, 2003 [1933]:160). Although such an explanation cannot be rejected, Mises does not provide evidence to underpin his hypothesis and neither have I been able to find supporting evidence. Even if it were true, it could not explain all the observations of the confusion of Homo stramineus with Homo economicus by so many people with such diverse ideological views.

Another explanation, entertained by e.g. Machlup (1972), is the ignorance of the critics of Homo economicus. For instance, John Ruskin, according to Machlup one of the "most overrated writers of nineteenth-century England", was even proud of not having read any economic books except for Wealth of Nations (Machlup, 1972:102). Indeed, rereading Senior, Mill, Marshall or Samuelson gives an impression that the critics did not read these authors carefully enough since possible objections to the concept are already anticipated in their works. Admittedly, there were important economists who put forward Homo stramineus as the representative species of the economic habitat. Cairnes, for instance, in one place identifies the desire of wealth with self-love (Cairnes, 1875[1857]:36-37); Edgeworth, in the favourite passage of the critics of Homo economicus, famously claims that the "first principle of Economics is that every agent is actuated only by self-interest" (Edgeworth, 1881:16), ${ }^{24}$ by which he means egoism (as opposed to utilitarianism, which according to him is the first principle of ethics). These occasional references to selfishness can be divided into two groups: the first must be considered slips of the pen (as in Cairnes' case), which are, in the context of other writings, not representative; ${ }^{25}$ the second are views of a group of economists writing during or shortly after the marginalist revolution (apart from Edgeworth this group would include also Jevons). The views of these economists were quickly replaced by Marshallian, Mengerian and Paretian approaches, which denied the link between economics and selfishness. In any case, the frequency of the occurrence of Homo stramineus in the writings of economists has been declining over time.

Although ignorance of what economists do could possibly account for some of the confusion of the two Homines, something must still be missing: Stigler, a historian of economic thought of note, who cannot be suspected of not reading Senior or Mill, describes economic man, portraying him as a somewhat selfish creature, striving for his own welfare, the welfare of his family and of a narrow circle of associates (Stigler, 1980:189). Fortunately, Stigler's deviation from the standard concept of Homo economicus seems to be clear: his concern is the "constant temptation to define the utility of the individual in such a way that the hypothesis is tautological" (Stigler, 1980:189). ${ }^{26}$ If all motives are

24 This statement by Edgeworth is quoted by Sen (1977) and Henrich et al. (2005) as evidence that economists assume selfishness.

25 Further examples include e.g. Pantaleoni (1957[1894]) and Arrow and Hahn (1983[1971]).

26 The fear that Homo economicus becomes a tautology has been widespread. The authors who refer to this problem include e.g. Etzioni (1990) and Rosenberg (1992). One solution to it is suggested by Mises (1996) and further developed by Rothbard (1977[1956], 2004[1962]), Hoppe (1995), Smith (1990, 1996) and Pavlík (2004, 2006). 
allowed to enter an individual's utility function, so is the fear of Stigler, the model loses its empirical content. ${ }^{27}$ Stigler's concern is largely unfounded because, as he was certainly aware himself, the Homo economicus model is in principle testable even if the motives are not specified: if inconsistent choices are observed, then the prediction of the model is violated. Admittedly, practical tests are difficult to carry out and they can always be interpreted as being in accord with the model. However, the practical difficulty of making empirical tests is not circumvented by Stigler's approach as all intentional approaches to behaviour necessarily suffer from it (Rosenberg, 1992).

It is fair to point out in this context that when the Homo economicus model is applied to real world phenomena, the content of the utility function has to be specified; in addition, almost all the action in explanation is probably performed by this auxiliary assumption about the content (and also the shape) of the utility function (Simon, 1986). Yet, it must be emphasized that even in applied economics selfishness is not a typical assumption and certainly not an unavoidable one. It is perhaps more correct to say that economists often follow the classics in assuming that "actors are motivated to attain private and instrumental goods such as wealth - or, less commonly, power and prestige - that are exchangeable for other immanent goods that are valued sui generis" (Hechter, 1994:318-319), with keeping in mind that in principle anything can be included in the utility function. To use the terminology of Machlup (1955), Homo economicus is the 'fundamental assumption' which is filled in with empirical content when applied to concrete phenomena. ${ }^{28}$ This empirical content is relative to the explanandum at hand and is not part of the Homo economicus model. To tie economic man with the motives that he sometimes (but not always) pursues, may also result in the unnecessary and unfortunate confusion of this creature with Homo Stramineus.

\section{Conclusion}

This paper has attempted to protect Homo economicus from the illegitimate charge of being a selfish creature; moreover, it has tried to identify the causes of this charge. The prevalence of misinterpretations of Homo economicus suggests that economists do not make sufficient effort to clarify its methodological status. The focus on the conceptual basis of economics cannot only dispense with the misinterpretations; it can also contribute to the solution of substantial problems, which continue to persist at the very heart of economics. For instance, the issue of empirical content of the Homo economicus model remains an open question which still awaits a satisfactory and generally acceptable answer. Likewise, to demonstrate which conclusions of economic theory are independent of their behavioural assumptions is another challenge that remains to be faced.

27 Elsewhere, he states the fact that people do not usually drink crankcase oil as a piece of evidence that people do not minimize utility (Stigler, 1966[1946]:59), implicitly suggesting that utility is something objectively definable.

28 For similar views see Buchanan (1979) and more recently Špecián (2012). 


\section{References}

Arrow, K. J., Hahn, F. (1983[1971]), General Competitive Analysis. Amsterdam: North-Holland.

Barton, J. (1830), A Statement of the Consequences Likely to Ensue from Our Growing Excess of Population, If Not Remedied by Colonization. London: Harvey and Darton.

Becker, G. S. (1998[1996]), Accounting for Tastes. Cambridge: Harvard University Press.

Becker, G. S. (1976), The Economic Approach to Human Behavior. Chicago: University of Chicago Press.

Bentham, J. (1817), A Table of the Springs of Action. London: Hunter.

Bentham, J. (1907[1823]), An Introduction to the Principles of Morals and Legislation. London: Clarendon Press.

Bentham, J. (1843), The Works of Jeremy Bentham. Vol. 10. Edinburgh: W. Tait.

Bernheim, B. D., Rangel, A. (2007), "Toward Choice-Theoretic Foundations for Behavioral Welfare Economics." American Economic Review, Vol. 97, No. 2, pp. 464-470.

Binmore, K. G. (2009), Rational Decisions. Princeton: Princeton University Press.

Böhm-Bawerk, E. von (1959[1889]), Capital and Interest: Positive Theory of Capital. South Holland: Libertarian Press.

Bowles, S., Gintis, H. (2000), “Walrasian Economics in Retrospect." The Quarterly Journal of Economics, Vol. 115, No. 4, pp. 1411-1439.

Bruni, L., Sugden, R. (2007), “The Road Not Taken: How Psychology Was Removed from Economics, and How It Might Be Brought Back." Economic Journal, Vol. 117, No. 516, pp. 146-173.

Buchanan, J. M. (1979), What Should Economists Do? Indianapolis: Liberty Press.

Cairnes, J. E. (1875[1857]), The Character and Logical Method of Political Economy. London: Longman, Brown, Green, Longmans and Roberts.

Caporael, L. R., Dawes, R. M., Orbell, J. M., van de Kragt, A. J. C. (1989), “Selfishness Examined: Cooperation in the Absence of Egoistic Incentives." Behavioral and Brain Sciences, Vol. 12, No. 4, pp. 683-699.

Carey, H. C. (1865), Principles of Social Science. Philadelphia: J. B. Lippincott \& Co.

Conlisk, J. (1996), "Why Bounded Rationality?" Journal of Economic Literature, Vol. 34, No. 2, pp. 669-700.

Cowen, T. (1989), "Are All Tastes Constant and Identical?: A Critique of Stigler and Becker." Journal of Economic Behavior \& Organization, Vol. 11, No. 1, pp. 127-135.

Davenport, H. J. (1902), "Proposed Modifications in Austrian Theory and Terminology." The Quarterly Journal of Economics, Vol. 16, No. 3, pp. 355-384.

Davenport, H. J. (1968[1914]), The Economics of Enterprise. New York: A. M. Kelley.

Downey, E. H. (1910), "The Futility of Marginal Utility." The Journal of Political Economy, Vol. 18, No. 4, pp. 253-268.

Edgeworth, F. Y. (1881), Mathematical Psychics. London: C. Kegan Paul \& Co.

Elster, J. (1989), Nuts and Bolts for the Social Sciences. Cambridge: Cambridge University Press.

Engliš, K. (1992), Economics: A Purpose Oriented Approach. New York: Columbia University Press.

Etzioni, A. (1990[1988]), The Moral Dimension: Toward a New Economics. New York: Simon and Schuster. 
Fehr, E., Fischbacher, U., Gächter, S. (2002), "Strong Reciprocity, Human Cooperation, and the Enforcement of Social Norms." Human Nature, Vol. 13, No. 1, pp. 1-25.

Fisher, I. (1918), "Is 'Utility' the Most Suitable Term for the Concept it is Used to Denote?" The American Economic Review, Vol. 8, No. 2, pp. 335-337.

Fisher, I. (2007[1892]), Mathematical Investigations in the Theory of Value and Prices, and Appreciation and Interest. Cosimo, Inc.

Force, P. (2003), Self-Interest before Adam Smith: A Genealogy of Economic Science. Cambridge: Cambridge University Press.

Gide, C. (1933[1883]), Principles of Political Economy. London: Harrap.

Griswold, C. L. (1999), Adam Smith and the Virtues of Enlightenment. Cambridge: Cambridge University Press.

Hadley, A. T. (1894), “Recent Tendencies in Economic Literature." Yale Review, No. 3, pp. 251-260.

Hayek, F. A. (1991), The Trend of Economic Thinking: Essays on Political Economists and Economic History. Vol. 3 of the Collected works of F. A. Hayek, W. W. Bartley III and Stephen Kresge (eds.). London: Routledge.

Hechter, M. (1994), "The Role of Values in Rational Choice Theory." Rationality and Society, Vol. 6, No. 3, pp. 318-333.

Henrich, J. et al. (2005), "In Cross-Cultural Perspective: Behavioral Experiments in 15 SmallScale Societies." Behavioral and Brain Sciences, Vol. 28, No. 6, pp. 795-815.

Hicks, J. R. (1986[1956]), A Revision of Demand Theory. Oxford: Oxford University Press. (1983), Classics and Moderns. Cambridge: Harvard University Press. (1946[1939]), Value and Capital: An Inquiry into Some Fundamental Principles of Economic Theory. Oxford: Oxford University Press.

Hicks, J. R., Allen, R. G. D. (1934a), "A Reconsideration of the Theory of Value. Part I." Economica, Vol. 1, No. 1, pp. 52-76.

(1934b), "A Reconsideration of the Theory of Value. Part II. A Mathematical Theory of Individual Demand Functions." Economica, Vol. 1, No. 2, pp. 196-219.

Hildebrand, B. (1848), Nationalökonomie der Gegenwart und Zukunft. Frankfurt am Mein: J. Rütten.

Hoppe, H.-H. (1995), Economic Science and the Austrian Method. Auburn: Ludwig von Mises Institute.

Houthakker, H. S. (1961), "The Present State of Consumption Theory." Econometrica, Vol. 29, No. 4, pp. 704-740.

Hudík, M. (2007), "František Čuhel (1962-1914)." New Perspectives on Political Economy, Vol. 3, No. 1, pp. 15-25.

(2011), "Why Economics Is Not a Science of Behaviour." Journal of Economic Methodology, Vol. 18, No. 2, pp. 147-162.

Jevons, W. S. (1965[1871]), Theory of Political Economy. New York: Augustus M. Kelley.

Kauder, E. (1965), A History of Marginal Utility Theory. Princeton: Princeton University Press.

Kirzner, I. M. (1976), The Economic Point of View: An Essay in the History of Economic Thought. Kansas City: Sheed and Ward.

Leslie, T. E. C. (1997 [1862]), "The Love of Money." in Backhouse, R. E., ed., The Methodology of Economics: Nineteenth-Century British Contributions. Volume 5. Historical Economics, 1870-1907. London: Routledge/Thoemmes. 
Lipka, D. (2012), “The Max U Approach: Prudence-Only, or Not Even Prudence? A Smithian Perspective." ICER Working Paper, No. 6/2012.

Luce, R. D., Raïffa, H. (1989[1957]), Games and Decisions: Introduction and Critical Survey. New York: Courier Dover Publications.

Machlup, F. (1955), "The Problem of Verification in Economics." Southern Economic Journal, Vol. 22 , No. 1, pp. 1-21.

(1972), "The Universal Bogey." in Preston, M., Corry, B., eds., Essays in Honour of Lord Robbins. London: Weidenfeld and Nicolson.

Malthus, T. R. (1827), Definitions in Political Economy. London: J. Murray.

(1836[1820]), Principles of Political Economy Considered with a View to Their Practical Application. London: W. Pickering.

Marshall, A. (1982[1890]), Principles of Economics: An Introductory Volume. Philadelphia: Porcupine Press.

Mas-Colell, A., Whinston, M. D., Green, J. R. (1995), Microeconomic Theory. Oxford: Oxford University Press.

McCloskey, D. N. (2011), Bourgeois Dignity: Why Economics Can't Explain the Modern World. Chicago: University of Chicago Press.

Menger, C. (1950[1971]), Principles of Economics. Glencoe: Free Press.

Mill, J. (1869), Analysis of the Phenomena of the Human Mind. London: Longmans, Green, Reader, and Dyer.

Mill, J. S. (1844), Essays on Some Unsettled Questions of Political Economy. London: J. W. Parker.

(1909[1848]), Principles of Political Economy: With Some of Their Applications to Social Philosophy. London: Longmans, Green, and Company.

Mises, L. von (2003[1933]), Epistemological Problems of Economics. Auburn: Ludwig von Mises Institute.

(1996[1949]), Human Action: A Treatise on Economics. San Francisco: Fox \& Wilkes.

Mitchell, W. C. (1910a), "The Rationality of Economic Activity." The Journal of Political Economy, Vol. 18, No. 3, pp. 197-216.

(1910b), "The Rationality of Economic Activity: I." The Journal of Political Economy, Vol. 18, No. 2, pp. 97-113.

Newcomb, S. (1966[1885]), Principles of Political Economy. New York: A. M. Kelley.

Ostrom, E. (1997), "A Behavioral Approach to the Rational Choice Theory of Collective Action: Presidential Address, American Political Science Association." The American Political Science Review, Vol. 92, No. 1, pp. 1-22.

Pantaleoni, M. (1957[1894]), Pure Economics. New York: Kelly \& Millman.

Pareto, V. (1971[1906]), Manual of Political Economy. New York: A. M. Kelley.

Pavlík, J. (2006), "Austrian Economics and the Problems of Apriorism." ELOGOS - Electronic Journal for Philosophy/2006.

(2004), F. A. Hayek a teorie spontánního řádu. Prague: Professional Publishing.

Pigou, A. (2006[1920]), The Economics of Welfare. Cosimo, Inc.

Robbins, L. (1945[1932]), An Essay on the Nature and Significance of Economic Science. London: Macmillan.

Rosenberg, A. (1992), Economics: Mathematical Politics or Science of Diminishing Returns? Chicago: University of Chicago Press. 
Rothbard, M. N. (2004[1962]), Man, Economy, and State. Auburn: Ludwig von Mises Institute. (1977[1956]), Toward a Reconstruction of Utility and Welfare Economics. New York: Center for Libertarian Studies.

Rubinstein, A. (1998), Modeling Bounded Rationality. Cambridge: MIT Press.

Rubinstein, A., Salant, Y. (2012), "Eliciting Welfare Preferences from Behavioural Data Sets." The Review of Economic Studies, Vol. 79, No. 1, pp. 375-387.

Ruskin, J. (1862[1860]), Unto this Last. London: George G. Harrap.

Salant, Y., Rubinstein, A. (2008), '('A', 'f'): Choice with Frames." Review of Economic Studies, Vol. 75, No. 4, pp. 1287-1296.

Samuelson, P. A. (1938), "A Note on the Pure Theory of Consumer's Behaviour." Economica, Vol. 5, No. 17, pp. 61-71.

(1974[1947]), Foundations of Economic Analysis. New York: Atheneum.

Say, J. B. (1836[1803]), A Treatise on Political Economy: Or the Production, Distribution, and Consumption of Wealth. Philadelphia: Grigg \& Elliot.

(1840[1828-30]), Cours complet d'économie politique pratique. Paris: Guillaumin.

Sen, A. (1993), "Internal Consistency of Choice." Econometrica, Vol. 61, No. 3, pp. 495-521.

(1977), "Rational Fools: A Critique of the Behavioral Foundations of Economic Theory." Philosophy and Public Affairs, Vol. 6, No. 4, pp. 317-344.

Senior, N. W. (1831 [1827]), Introductory Lecture on Political Economy. London: J. Murray. (1854[1850]), Political economy. London: Richard Griffin.

Schumpeter, J. A. (1994[1954]), History of Economic Analysis. London: Routledge.

Simon, H. A. (1986), "Rationality in Psychology and Economics." The Journal of Business, Vol. 59, No. 4, pp. S209-24.

Slutsky, E. E. (1998[1915]), "On the Theory of the Budget of the Consumer." in Lancaster, K. ed., Consumer Theory. Cheltenham: Elgar, pp. 3-32.

Smith, A. (2007[1759]), The Theory of Moral Sentiments. Minneapolis: Filiquarian Publishing, LLC. (2008[1776]), The Wealth of Nations. Paw Prints.

Smith, B. (1990), "Aristotle, Menger, Mises : An Essay in the Metaphysics of Economics." History of Political Economy, Vol. 22, pp. 263-288.

(1996), "In Defense of Extreme (Fallibilistic) Apriorism.” Journal of Libertarian Studies, Vol. 12, No. 1, pp. 179-192.

Smith, V. (2007), Rationality in Economics: Constructivist and Ecological Forms. New York: Cambridge University Press.

Stigler, G. J. (1980), "Economics or Ethics?" in McMurrin, S. M., ed., Tanner Lectures on Human Values. Salt Lake City, Cambridge: University of Utah Press, Cambridge University Press.

(1950a), "The Development of Utility Theory. I." The Journal of Political Economy, Vol. 58, No. 4, pp. 307-327.

(1950b), "The Development of Utility Theory. II." The Journal of Political Economy, Vol. 58, No. 5, pp. 373-396.

(1976), "The Successes and Failures of Professor Smith." Journal of Political Economy, Vol. 84, No. 6, pp. 1199-1213.

(1966[1946]), The Theory of Price. New York: Macmillan. 
Syll, L. P. (1993), "Cassel and Revealed Preference Theory." History of Political Economy Vol. 25, No. 3, pp. $499-514$.

Špecián, P. (2012), "Od Misese k Schutzovi. Otázka Apriorismu v Ekonomii." Politická ekonomie, Vol. 60, No. 3, pp. 395-410.

Thompson, R. E. (1875), Social Science and National Economy. Philadelphia: Porter and Coates.

Tugwell, R. G. (1922), "Human Nature in Economic Theory." The Journal of Political Economy, Vol. 30, No. 3, pp. 317-345.

Varian, H. R. (2006), Revealed Preference, in Szenberg, M., Ramrattan, L., Gottesman, A. A., eds., Samuelsonian Economics and the Twenty-First Century. New York: Oxford University Press, pp. 99-115.

Veblen, T. (1898), "Why Is Economics Not an Evolutionary Science?" The Quarterly Journal of Economics, Vol. 12, No. 4, pp. 373-397.

Viner, J. (1925a), "The Utility Concept in Value Theory and Its Critics." The Journal of Political Economy, Vol. 33, No. 4, pp. 369-387.

(1925b), "The Utility Concept in Value Theory and Its Critics." Journal of Political Economy, Vol. 33, No. 6, pp. 638-659.

Weber, M. (1978[1922]), Economy and Society: An Outline of Interpretive Sociology. Berkeley: University of California Press.

Whately, R. (1847[1832]), Introductory Lectures on Political Economy. London: John W. Parker.

Whitehead, A. N. (1979[1929]), Process and Reality: An Essay in Cosmology. New York: Simon and Schuster.

Wicksteed, P. H. (1970[1888]), The Alphabet of Economic Science: Elements of the Theory of Value or Worth. New York: A. M. Kelley. (1957[1910]), The Common Sense of Political Economy: And Selected Papers and Reviews on Economic Theory. London: Routledge \& K. Paul.

Wieser, F. von (2003[1914]), Social Economics. London: Routledge. 